\title{
THE DEFENCE OF SUPERIOR ORDERS IN THE MODERN LAW OF ARMED CONFLICT
}

\section{L.C. GREEN ${ }^{*}$}

The Geneva Conventions of 1949 and their Additional Protocols refer to grave breaches of the laws of armed conflict and to punishment and prevention of such breaches. Even militan system demands obedience by inferiors to the orders of superiors. A principle of customary law requires an inferior to discobey orders that are so manifestly. illegal that he must or ought to have know that they were unlawful.

Despite the silence of the Geneta Conventions and Protocol I on defences that might be raised by anyone charged with such breaches, the customary law regarding war crimes applies not only io offences against the law's and customs of war but to breaches of the Geneva Comentions and the Protocol.

This situation has not changed substantially as a result of the Drafi Code of Crimes Against the Peace and Security of Mankind as it reiterates the provisions established in customary las: If adopted. it would provide a treaty provision recognizing the limited validity of the defence of superior orders not for all war crimes but for those which are "exceptionally serious" and for nther crimes against peace and security. War crimes in the Iraditional sense and "grave breaches" described in the Geneva Conventions and Protocol I are dealt with by customary law:
Les Conventions de Genève de 1949 et leurs Protocoles additionnels traitent de la violation des lois sur les conflits armés, et des sanctions et des mesures visant à prévenir celte violation. Tout système militaire repose sur l'obéissance aux ordres des supérieurs. Un principe du droil coutumier exige par ailleurs d'un soldat qu'il se soustrait aux ordres qui sont si manifestement illicites qu'on s'attende d̀ ce qu'il en soit conscient.

Malgré le silence des Conventions de Genève et du Protocole I sur les arguments que peut invoquer toute personne ainsi accusée, le droil coutumier relatif aux crimes de guerre s'applique non seulement à linobservation des lois ef coutumes de guerre, mais aussi aux violations des Conventions de Genève et du Protocole.

La situation a peu changé suite au projet du Code des Crimes contre la paix générale et la sécurité des peuples. qui réitère les dispositions du droit coutumier. S'il était adopté. il prévoiruit la validité limitée de la défense invoquant la nécessité d'obéir aux ordres diun supérieur non pas pour tous les crimes de guerre. mois pour ceux qualifiés d'aexceptionnellement gruvess et pour les autres crimes contre la paix et la sécurite. Au sens traditionnel. le droit coutumier traite des crimes de guerre et des violations graves que décrivent les Conventions de Genìve ef le Protocole I.

\section{TABLE OF CONTENTS}

I. GENEVA CONVENTIONS AND PROTOCOLS $\ldots \ldots \ldots \ldots \ldots 321$

II. OBLIGATION TO OBEY SUPERIOR ORDERS $\ldots \ldots \ldots \ldots \ldots .321$

III. ILLEGAL ORDERS $\ldots \ldots \ldots \ldots \ldots \ldots \ldots \ldots \ldots \ldots \ldots \ldots \ldots \ldots$

IV. HISTORICAL VIEW OF ORDERS AND

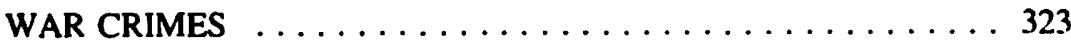

V. THE NUREMBERG PRINCIPLES $\ldots \ldots \ldots \ldots \ldots \ldots \ldots \ldots 326$

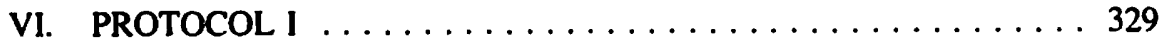

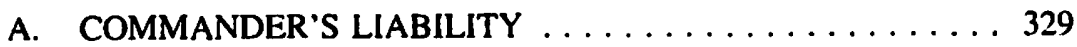

B. THE DISTINCTION BETWEEN GRAVE

AND OTHER BREACHES $\ldots \ldots \ldots \ldots \ldots \ldots \ldots \ldots$

VII. THE DRAFT CODE OF CRIMES AGAINST MANKIND ..... . 331

C.M.. LL.B.. 1.I..D., F.R.S.C.: Universily Professor Emeritus. Honorary Professor of Law. University of Alberta. Canada. Based on an address delivered at the British Institute of International Comparative law. 25 Feb., 1991. 


\section{GENEVA CONVENTIONS AND PROTOCOLS}

It is perhaps surprising that neither the Geneva Conventions of $1949^{\prime}$ nor the Additional Protocols thereto of $1977^{2}$ make reference to any defenses that might be raised by persons charged with breaches thereof. This is despite the fact that Protocol I makes provision for the liability of the commander." This means that in assessing the significance of the defence of superior orders ${ }^{4}$ to a charge of war crimes or crimes against humanity, recourse must be had to both the international customary law of armed conflict and the relation of that defence to the above Conventions and Protocols.

\section{OBLIGATION TO OBEY SUPERIOR ORDERS}

It is almost a truism to assert that every military system demands obedience by inferiors to the orders of superiors. In his Digest Justinian stipulates that "any person who, in war, commits any act forbidden by his commander, or fails to obey his orders, shall suffer death, even if his mission be successfully accomplished." In the Articles of War promulgated by Richard II in $1385^{\circ}$ it is provided that "every one be obedient to his captain... under penalty of losing his horse and armour." while James II provided, in 1688. that "if any inferior officer or soldier shall refuse to obey his superior officer... he shall be cashiered, or suffer such punishment as a Court Martial shall think fit." Similar provisions appeared in the military instructions laid down by the Emperor Maximilian, in those of Robert, Earl of Leicester, when commanding the Netherlands and English forces in 1586, and in the Letter of Articles on Military Discipline made by Prince Maurice of Orange which was in force until $1799 .{ }^{\circledR}$

\section{ILLEGAL ORDERS}

There gradually developed the principle that it was only to lawful orders that such obedience had to be shown. although there was little guidance to the man in the field as to how he was to determine which orders were in fact lawful." The first edition of the

I-Wounded and Sick in the Field: II-Wounded, Sick and Shipwrecked at Sea; III-Prisoners of War: IV-Civilians. in D. Schindler and J. Toman. The Laws of Armed Comflicts 3d ed. (Boston: Nijhofr, 1988). I-International Armed Conflicts: II-Non-International Armed Conflicts, in Schindler \& Toman, supra note 1 at 621.689.

lbid. Arts. 86. 87 at 672.

See L.C. Green. Superior Orders in National amd Imermutional Law (Leyden: Sijthoff, 1976); Y. Dinstein. The Defence of 'Obedience io Superior Orders' in International Law (Leyden: Sijthoff. 1965); N. Keijzer. Militury Ohedience (Alphen aan/den Rijn: Sijthoff. 1978).

An. XLIX. tit. Xvi, de re militari.

" W. Winthrop, Milinary Lum and Precedents (New York: Arno Press. 1979) ftem XVI at 904 appendix III.

- Ibid. Art. XV appendix V. at 922.

* Sce Keijzer. supra note 4 at 73.

" See L.C. Green. "Superior Orders and the Man in the Field". in L.C. Green, cd., Eissarys on the Modem La" of War (Dobbs Ferry, N.Y: Transnational. 1985) 44. 


\title{
British Manual of Military Law" states:
}

If the command were obviously illegal, the inferior would be justified in questioning or cven in refusing to execute it, as for instance if he were ordered to fire on a peaceable and unoffending bystander. But so long as the orders of the superior are not obviously and decidedly in opposition to the law of the land or to the well-known and established custom of the army, so long must they mect prompt, immediate and unhesitating obedience.

This statement should be read next to the 'Lesson Plan' on the Geneva Conventions prepared by the United States Department of the Army in 1970" in the light of some of the acts committed in Vietnam:

\begin{abstract}
...Acting under superior orders is no defence to criminal charges when the order is clearly illegal.... While an American soldier must promptly obey all legal orders, he also must disobey an order which requires him to commit a criminal act in violation of the law of war. An order to commit a criminal act is illegal.... In some cases, orders which should be legal in some situations may be illegal in others. The nules of engagement will guide your actions. ... By knowing these Rules you will be able to act properly in different situations. If you disobey the rules of engagement, you can he tried and punished for disobedience to orders. This disobedience may also be a war crime for which you may be tried and punished.... You should not presume an order is illegal. If you think it is illegal. it is probably because the order is unclear.... Rather than presume that an unclear order directs you to commit a crime, ask your supcrior for clarification of the order.... But suppose you are given an illegal order.... What do you do? First and most important you should try and get the order rescinded by informing the person who gave it that the order violates the law of war.
\end{abstract}

One cannot help but feel that whoever wrote this 'Lesson Plan' had little knowledge of the realities of army life or had ever come into contact with a regular sergeant.

\section{The 'Lesson Plan' continues:}

[If the person giving the order| persists, you must disregard such an illegal order. This takes courage |!|. but if you fail to so do you can be tried and punished for committing a criminal act in violation of the law of war. No one can force you to commit a crime, and you cannot be court martialled or given any uther form of punishment for your refusal to obey. The lack of courage to disregard an illegal order, or a mistaken belief that you will be cour martialled for disobedience to orders is not a defence to a chargc of ... war crime.

This sounds very fine in time of peace. However, at the front and in the heat of battle it may be questionable how far the superior order will be disobeyed on the basis that the recipient considers it illegal. This will result in a commander trying by "drumbead" court martial the individual he considers disobedient in the face of the enemy. The fact that the at 22.

11 Dept. of the Army. AsubjScd 2701, 8 Oct. 1970. This is discussed in some detail in L.C. Green. "Aftermath of Victnam: War Law and the Soldier" in R. Falk. ed., The Viernam War and Intemational Law vol. 4 (Princeton: Princeton University Press, 1976) at 147, 168-172. 
superior may subsequently be tried for murder will not be of much consolation to the soldier who has been executed.

\section{HISTORICAL VIEW OF ORDERS AND WAR CRIMES}

This type of reasoning is similar to the decisions of the English courts which tried the regicides after the restoration of Charles II. In so far as Cooke, Chief Justice of Ireland, was concerned, the reasoning was simple. Cooke had presented the indictment and demanded judgment against the King. To his plea that "they were not my words, but their words that commanded me," the court replied:"2

you know hy a printed authority. that where a settled court, a true courn is, if that courn meddle with that which is not in the recognizance. it is purely void; the minister that oteys them is punishable: if it be treasonable matter, it is treasion.... You speak of a court: 1 . it was not a court; 2 . No courts whatsucver could have any power over a king in a coercive way as to his person.... IT/he acting by colour of that pretended authority was far from any pretended extenuation, that it was an aggravation of the thing.

In this case it could be said that the Chief Justice as a man of law should have known that it was treasonable to participate in the trial and sentencing of his monarch. However, the court held that the same principle applied in the case of a mere soldier who was commander of the guard at the king's execution: ${ }^{13}$

[Axtell] justified that all he did was as a soldier, by the command of his superior officer whom he must obey or die. It was resolved that was no excuse. for his superior was a traitor and all who joined with him in that act were traitors and did hy that. approve the treason: and where the command is traitorous, then the obedience to that command is also traitorous.

More significant from the point of view of the law of war is the trial that took place in Breisach of Peter of Hagenbach in $1474^{14}$ for a series of offences which would today be described as war crimes or crimes against humanity. Peter of Hagenbach. Charles of Burgundy's Governor of Breisach, was tried on the orders of the Archduke of Austria and his Allies by a tribunal made up of 28 judges drawn from Breisach, the other Allied Austrian and Upper Rhenish towns, Berne, a member of the Swiss Confederation and Solothurn, allied with Berne. The charges included "murder, rape, perjury, and other malefacta, including orders to the non-German mercenaries he had brought to Breisach, to kill the men in the houses where they were quartered so that the women and children would be completely at their mercy." Foretelling the charges specified in the Treaty of Versailles against the Kaiser, ${ }^{15}$ Peter was alleged to have "trampled under foot the laws of God and man." In his defence it was submitted that:

12 (1660), 5 State Trials at $1111,1115$.

1. Axtell's Case (1661), Kelying 13, 84 E.R. 1055 at 1060).

is See "The Breisach Trial of 1474" in G. Schwarzenberger, International Law', vol. II, (London: Stevens and Son, 1968) at $\mathbf{4 6 2}$.

is Art. 227 "... a supreme offence against international morality." 
Sir Peter von Hagenbach does not recognize any other judge and master than the Duke of Burgundy from whom he had received his commission and his orders. He had no right to question the orders that he was charged to carry out. and it was his duty to ubey. Is it not known that soldicrs owe absolute obedience to their superiors? Docs anyone believe that the Duke's Landvogt 1-provincial governor or high bailif-I could have remonstrated with his master or have refused to carry out the Duke's orders? Had not the Duke by his presence subsequently confirmed and ratified all that had been done in his name?

The tribunal was not impressed and held such a defence to be contrary to the law of God, and Peter of Hagenbach was duly sentenced and executed.

Coming to more recent times there is the case of $R$. v. Smith ${ }^{16}$ relating to the treatment of internees during the Boer (South African) War. The killings in issue had been committed on the orders of an officer, but Solomon J.P. stated:

It is monstrous to suppose that a soldicr would be protected where the order is grossly illegal. |But that hel is responsible if he obeys an order that is not strictly legal is an extreme proposition which the Court cannot accept.... tispecially in time of war immediate obediencc ... is required. ... I think it is a sale rule to lay down that if a soldier honestly believes that he is doing his duty in obeying the commands of his superior, and if the orders are not so manifestly illegal that he must or ought to have known that they were unlawful, the private soldier would be protected by the order of his superior officer.

This dictum has come to be generally accepted as a clear and specific comment on the nature of an inferior's obligations.

From the point of view of the modern approach to the defence, the decision of the German Reichsgericht at Leipzig in the Llandovery Castle ${ }^{17}$ is more significant. The accused were charged with the unlawful sinking of a hospital ship and firing upon survivors. In rejecting their plea of obedience to superior orders, the court stated:

...The killing of enemies in war is in accordance with the law of the State that makes war.... only in so far as such killing is in accordance with the conditions and limitations imposed by the Law of Nations. The fact that his deed is a violation of International Law must be well known to the doer. apart from acts of carelessness in which careless ignorance is a sufficient excuse.... The rule of International Law which is here involved, is simple and universally known.... (The commander's/ order does not free the accused from guilt. It is true that according to s. 47 of the /German| Military Penal Code, if the execution of an order in the ordinary course of duty involves such violation of the law as is punishable, the superior officer issuing such an order is alone responsible. According to paragraph 2. however, the subordinate obeying an order is liuble to punishment, if it is known to him that the order of the superior involved the infringement of civil or military law. This applies to the case of the accused. It is certainly to be urged in favour of the military subordinates that they are under no ohligation to question the order of the superior officer, and thcy can count upon its legality. But no such confidence can be held (1) exist, if such

(1900)). 17 S.C. at 561. 567-8 (Cape of Good Hope). See also, the case of Breaker Morant in which the defence claimed the accused were acting in accordance with orders issued by Kitchener, in $\mathbf{G}$. Witton. Scapegouts of the Empire (Melbourne: D.W. Paterson. 1907). 
an order is known universally to everybody, including the accused, to be without any doubt whatever against the law.... They should certainly have refused to obey the order.... They had acquired the habit of obedience to military authority and could not rid themselves of it. This justifies the recognition of mitigating circumstances in determining the punishment.

This decision of the Reichsgericht does not appear to have affected the views of those responsible for preparing the land war manuals of Germany's former enemies. ${ }^{18}$ Nor did it affect the various editors of Oppenheim, whose International Law was regarded as the leading monograph in English. The (third) first post-war edition, prepared by Roxburgh, repeats Oppenheim's original statement in $\$ 253^{19}$ that "members of the armed forces [who] commit violations by order of their Government, ....are not war criminals and may not be punished by the enemy," but adds by way of footnote, without mentioning the Llandovery Castle, "the contrary is sometimes asserted... [but] the law cannot require an individual to be punished for an act which he was compelled by law to commit." The same is true of the 4th edition by McNair, but in the 5th, the first edited by Lauterpacht, the footnote is expanded to state that the Llandovery Castle judgment held "that the defence of superior orders was manifestly and indisputably contrary to International Law," but this is treated as if it were a deviation from the norm. When he issued a revised edition in 1940, Lauterpacht altered the entire tenor of Oppenheim's original statement. The paragraph in question now read:

The fact that a rule of warfare has been violated in pursuance of an order of the belligerent Government or of an individual belligerent commander does not deprive the act in question of its character as a war crime; neither does it, in principle. confer upon the perpetrator immunity from punishment by the injured belligerent. A different view has occasionally bcen adopted in military manuals and by writers, but it is difficult to regard it as expressing a sound legal principle.

In the footnote, Lauterpacht cites the British and American Manuals, together with "the previous editions of this volume" including his own. He went on to indicate:

a Court confronted with the plea of superior orders adduced in justification of a war crime is bound to take into consideration the fact that obedience to military orders, not obviously unlawful, is the duty of every member of the armed forces and that the latter cannot, in conditions of war discipline, be expected to weigh scrupulously the legal merits of the order received.... However. ...the question is governed by the major principle that members of the armed forces are bound to obey lawful orders only and that they therefore cannot escape liability if, in obedience to command, they commit acts which both violate unchallenged rules of warfare and outrage the general sentiment of humanity.

As authority for these changes in the relevant section of Oppenheim, Lauterpacht cites the Llandovery Castle decision. Moreover, the text of this new version was embodied expressiss verbis in an amendment to the British Manual, to be followed shortly thereafter Stationary Office, 1929) s. 443; see also the 1940 edition of United States, Dept. of the Army. The Law of Land Warfare (Washington, 1940), s. 366. 
by a similar amendment to the United States equivalent. In regard to this amended version of the text Lauterpacht states that "a different view has occasionally been adopted in military manuals and by writers $\quad$ n. 2, see, e.g., s. 253 of the previous editions of this work , but he docs not refer to the fact that he edited an edition containing this former assertion.

In some of the war crimes trials held after World War Il the discrepancies in the literature and the military manuals resulted in controversy as between the prosecution and the defence, with tribunals pointing out that: ${ }^{20}$

the fact that the British and American armies may have adopted |Oppenheim's view| for the regulation of their own armies as a matter of policy. does not have the effect of enshrining it as a rule of International Law.... Army regulations are not a competent source of International Law.... It is possiblc. however, that such regulations, as they bear upon a question of custum and practice in the conduct or war, might have evidentiary valuc, particularly if the applicable portions had been put into general practice.... If the Count find that the army regulations of some members of the family of nations provide that superior order is a complete defence and that the army regulations of other nations express a contrary vicw, the Court would be obliged to hold... that the general acceptation of consent was lacking among the family of nations. Inasmuch as a substantial conflict exists among the nations whether superior order is a delence to a criminal chargc. it could only result in a further finding that the basis does not exist for declaring supcrior order to be a defence to an International Law crimc. But ... army regulations are not a compctent source of Intemational Law when a fundamental rule of justice is concerned.... This leaves the way clear to the Court to affirmativcly declare that superior order is not a defence to an International Law crime if it finds that the principlc is a fundamental rulc of justice and for that reason has found general acceptance. Intcrnational Law has never approved the defensive plea of supcrior order as a mandatory bar to the prosecution of war criminals... although if the circumstances warrant it may be considered in mitigation of punishment...

\section{THE NUREMBERG PRINCIPLES}

Far more significant than any of these statements, since it is embodied in an international agreement, is Article 8 of the Charter of the International Military Tribunal, Nuremberg." This stipulated that "the fact that the Defendant acted pursuant to order of his Government or of a superior shall not free him from responsibility, but may be considered in mitigation of punishment if the Tribunal determines that justice so requires." The Nuremberg Judgment considered this provision:22

in contormity with the law of nations. That a soldier was ordered to kill or torture in violation of the law of war has never been recognized as a defence to such acts of brutality. though as the Charter here provides, the order may be urged in mitigation of punishment. The true test. which is found in varying 
degrees in the criminal law of most nations," is not the existence of the order, but whether moral choice was in fact possiblc.... |l | ndividuals have international duties which transcend the national obligations of obedience imposed by the individual State. ${ }^{2-1}$ He who violates the law of war cannot obtain immunity while acting in pursuance of the authority of the State if the Statc is authorizing moves outside its competence under international law.... Superior orders. even 10 a soldier. cannot be considered in mitigation where crimes have been committed consciously, ruthlessly and without military excuse or justification.... Participation in such crimes as these has never been required of any soldier and |they| cannot now shield | themselves / behind a mythical requirement of soldierly obedience at all costs as | their| excuse for commission of those crimes.

The International Military Tribunal for the Far East contented itself with expressing its "complete accord... with the foregoing opinions of the Nuremberg Tribunal... rather than by reasoning the matters now in somewhat different language to open the door to controversy by way of conflicting interpretations of the two statements of opinion."25

Without going into any specifics, the General Assembly of the United Nations at its first session adopted a Resolution ${ }^{26}$ Affirming the Principles of International Law Recognized by the Charter of the Nuremberg Tribunal and the Judgment of the Tribunal. presumably including the references to superior orders. The Resolution also called upon the International Law Commission, with a view to preparing a code of offences against the peace and security of mankind, "to treat as a matter of primary importance" a statement of the same Principles. Principle IV of the Commissions's statement ${ }^{27}$ affirms that "the fact that a person acted pursuant to order of his Government or of a superior does not relieve him from responsibility under international law, provided a moral choice was in fact possible to him."

That national military courts after 1945 adopted a view of the defence of superior orders in relation to members of their own forces that coincides with this view of the defence, tends to confirm that it expresses customary international law on the subject. In Chief Military Prosecutor v. Malinki and Others (Kaffr Qassem casc) the Military Court of Appeal of Israelex adopted the comments of the District Military Court of the Central District:

The identifying mark of 'manifestly unlawful' order must wave like a black llag above the order given. as a warning saying 'forbidden". It is not formal unlawfulness hidden or half-hidden, not unlawfulness that is detectable only by legal experts, that is the important issue here, but an overt and salient violation of the law, a certain and obvious unlawfulness that stems from the order itself. the criminal character of

For a selection of judgments under national criminal law and by national war crimes tribunals, see Green, supra note 4 passim.

Sec, however, Lewy. "Superior Orders, Nuclear Warfare and the Dictates of Conscience: The Dilemma of Military Obedience in the Atomic Age" (1961) 55 Pol. Sci. Rev. 3 at 8.

Re Hirota and Others (1948). 15 Ann. Dig. 356 at 363.

Res. 95(I). 1946: Schindler \& Toman, supra note 1 at 921.

United Nations, International Law Commission. Yearhook of the Internetional Law Commission. vol II. 1950 at 375: and Schindler \& Toman, supra note 1 at 92.3.

Appeal 279-283/58. 44 Psakim (Judgments of the District Courts of Israel) 362: the English tr. uscd here is from (1985) 2 Palestinc Y.B. Int'l law 69 at 108. 
the order itself or of the acts it demands to be committed. an unlawfulness that pierces the eye and agitates the heart, if the eye be not blind nor the heart closed or corrupt. That is the degree of 'manifest' illegality required in order to annul the soldier's duty to obey and render him criminally responsible for his actions.

In this case, the Court of Appeal confirmed the guilty verdict delivered by the District Court. Later, in Attorney-General. Israel v. Eichmann, the District Court quoted this statement with approval, ${ }^{29}$ while the Supreme Court referred to the Nuremberg Principles, "which have become the legacy of civilized countries." ${ }^{\text {"3il }}$

Likewise, in its judgment concerning the criminal liability of Lieutenant Calley for the massacre at My Lai during Vietnam war, ${ }^{31}$ the judge advocate at his court martial ruled and this was approved by the Military Court of Appeal: ${ }^{32}$

...if you find that Lieutenant Calley received an order directing him to kill unresisting Vietnamese within his control or within the control of his troops, that order would be an illegal order. The question dres not rest there, however. A determination that an order is illegal does not. of itself, assign criminal responsibility to the person following the order for the act done in compliance with it.... The acts of a subordinate done in compliance with an unlawful order given him by his superior are excused and impose no criminal liability unless the superior's order is one which a man of ordinary sense and understanding would, under the circumstances. know to be unlawful, or if the order in question is actually known to the accused to be unlawtul... Knowledge on the part of the accused ... may be proved by circumstantial evidence. that is by evidence of facts from which it may justifiably be inferred that Licutenant Calley had knowledge of the unlawfulness of the order which he ... followed.... Unless you find beyond reasonable doubt that the accused acted with actual knowledge that the order was unlawful, you must procced to determine whether, under the circumstances, a man of ordinary sense and understanding would have known the order was unlawful. Your deliberations on this question do not focus solely on Lieutenant Callcy and the manner in which he perceived the legality of the order found to have been given him. The standard is that of a man of ordinary sense and understanding under the circumstances....

It is clear from these instances that at least some common law countries adopt the same approach to the defence of superior orders as did the two international military tribunals and the various other courts already mentioned.

While some surprise might be expressed that the Geneva Conventions of 1949 made no reference to the defence when listing the grave breaches which were considered punishable, it should be remembered that these instruments are concerned with the protection of those hors de combat, and, while listing some of the activities which would constitute breaches, to have provided details as to the treatment of offenders might well have gone beyond their scope. This is particularly so if one looks at the history of the development of the Geneva law beginning with the Resolutions of the 1863 Geneva

(1961) 36 I.R.L. 5 (District Court) at 256.

(1962) 36 I.L.R. 277 (Supreme Court) at 317-8.

U.S. v. Calley (197I) 48 C.M.R. 19 at 30-34.

Ibid. at 80-8I: other U.S. couns martial arising from the operations in Korea and Vietnam, involving the plea of superior orders, are discussed in Green, supra note 4 at 129-139. 
International Conference ${ }^{33}$ at which the Red Cross movement was founded. But it should be noted that the parties to the 1945 Conventions did undertake to enact penal legislation assuming jurisdiction over those committing grave breaches regardless of nationality, or agreeing to hand them over for trial to any party making out a prima facie case. In any such trial, the accused is to receive all the benefits of a proper trial and defence, including presumably any defences that might be available by treaty or customary law, which would mean the right to plead superior orders by way of mitigation. ${ }^{34}$

\section{PROTOCOL I}

\section{A. COMMANDER'S LIABILITY}

Protocol I on the other hand, while not making any provision for the defence of those charged with breaches of war crimes, expressly makes provision for the responsibility of commanders reflecting the decisions in $R e$ Yamashita ${ }^{35}$ and $R e$ Meyer. ${ }^{36} \mathrm{~A}$ commander is held responsible if he knew or "had information which should have enabled him to conclude in the circumstances at the time" that one of his subordinates "was committing or was going to commit [a breach and he] did not take all feasible measures within [his] power to prevent or repress the breach. ${ }^{.37}$ Moreover, a direct duty was placed upon commanders to "prevent and, where necessary, to suppress and report to competent authorities" any breaches of the 1949 Conventions or Protocol. ${ }^{38}$ Commanders were also required to ensure that troops under their command were made aware of their obligations under these instruments and legal advisers are to be attached to commanders to advise them "on the application of the Conventions and Protocol and on the appropriate instruction to be given." ${ }^{34}$ "Any commander who is aware that subordinates or other persons under his control are going to commit or have committed [any] breach ... [is] to initiate such steps as are necessary to prevent such violations ... and, where appropriate, to initiate disciplinary or penal action against [such] violators."

In view of these provisions attempts were made at the final 1977 session of the Geneva Conference to secure the adoption in Protocol I of an article on superior orders in respect of any person charged with a breach or other war crime. ${ }^{* 0}$ Since there is nothing in Protocol II relating to breaches, command responsibility or enforcement, no similar effort was made in regard to that document.

Schindler \& Toman, supra note I at 275.

Conv. I, Art. 49; Conv. III, Art. 105.

(1946) UNWCC 4 Law Reports 1 at 34-35.

(1945) The Abbaye Ardenne Case, ibid. 97. More complete extracts from the relevant portions of the judge advocate's summing up are to be found in Green, supra note 9 at 226-27: and L.C. Green, "Superior Orders and Command Responsibility" (1989) 27 Canadian Y.B. Int'I 167 at 196-198.

Art. 86.

Art. 87.

Art. 82. See also, Green. supra note 9 at 73-82.

The following account is based on the summary of the procedings prepared by $H$. Levic as a Supplement, 1985, to his four volumes of Conference documents entilled Protection of War Victims 4 vols. (Dobbs Ferry. N.Y.: Oceana, 1979). 


\section{B. THE DISTINCTION BETWEEN GRAVE AND OTHER BREACHES}

In Article 77 of its draft of Protocol I submitted to the Diplomatic Conference in 1977 the International Committee of the Red Cross had put forward a proposal concerning superior orders. The effect was to protect from punishment any person refusing to obey an order which would have involved commission of a grave breach, while at the same time denying the validity of the defence of superior orders if, "in the circumstances at the time, he should have reasonably known that he was committing a grave breach ... and that he had the possibility of refusing to obey the order." This proposal met a number of suggested amendments, particularly from countries which considered that the reference to 'grave breaches' might imply that a different position prevailed in the case of war crimes not amounting to grave breaches. Others sought to introduce 'wilfulness', while a third group wished to omit the final clause concerning the possibility of refusal of compliance. Ultimately, a draft dropping the concept of 'wilfulness' but introducing the term 'mere' between the opening 'The' and 'fact', and retaining the reference to 'gravity' was adopted by 38 votes to 22 , with 15 abstaining.

The United Kingdom was among those abstaining on the ground that the proposed text created a special regime for 'grave breaches', while other breaches of the Conventions or customary law remained under the aegis of customary law. It is submitted that this is by no means the case, for there was no suggestion that the proposal as drafted related to ordinary war crimes in any way, even though Article 85 (5) of the Protocol as finally adopted clearly states that "without prejudice to the application of the Conventions and the Protocol, grave breaches of these instruments shall be regarded as war crimes." It would appear, therefore, that any defence that is available in so far as a grave breach is concerned would be equally available to anyone charged with a war crime not amounting to a grave breach. Canada, too, opposed the draft on the ground that it might be contended that three different concepts were to apply the draft with regard to 'grave breaches', some other system to lesser breaches, and the Nuremberg Principles for other war crimes and crimes against humanity. In Plenary the United Kingdom and the United States voted against the adoption of any provision on superior orders, while Canada favoured the inclusion of such an article, especially as it had been agreed to vote on the various amendments and paragraphs separately.

Ultimately, the text put before the Plenary received 36 votes in favour, with 25 against and 25 abstentions. Since the proposal had not received a two-thirds majority it was rejected. The United States explained that it had opposed simply because it felt the reference to 'grave' unduly restricted the defence for it enabled states to refrain from indicating to what offences the defence would apply. The prevailing attitude of the Western powers, including those that abstained or opposed, was perhaps best expressed in the statement put forward by Canada in explanation of its vote. Having pointed out that there were articles relating to command responsibility, Canada maintained that logic demanded a provision of individual responsibility:"

41 This statement was drafted by the writcr in his rolc as legal adviser to the Canadian delegation at the Conference. 
We agree that under customary international law an accused is unable to plead as a defence that the criminal act with which he was charged was in compliance with supcrior orders that had been given to him. While denying this avenue of delence. the Canadian delegation is aware that compliance with an order to commit an act which the accused knew or should have known was clearly unlawful may be taken into consideration by way of mitigation of punishment.... [T/o deny the availability of this defence is in no way contrary to the maintenance of military discipline. Since all States are presumed to abide by the law and to intend to lulfil their obligations in good faith." $\mid$ we are $\mid$ convinced that no Statc will encourage or tolerate any of its commanders ordering their subordinates 10 commit an illegal act amounting to an act clearly contrary to the international law of armed conflict.... While we would have liked to see lan article on superior orders] as part of the Prollocol, we can console ourselves with the knowledge the article was in fact broadly in accordance with existing international law. which continues to operate in so far as breaches of the Conventions and the Prolociol are concerned.

It is submitted that, in light of customary law as it developed since medieval times, in national criminal law and the practice of military tribunals culminating in the Judgment of the Nuremberg Tribunal, this Canadian statement expresses the current position under international customary law. The Geneva Conventions and Protocol I are silent on this matter. As nothing in them indicates a contrary position, the customary law regarding war crimes applies not only to offences against the laws and customs of war as previously understood, but equally to all breaches of the Geneva Conventions and the Protocol.

\section{DRAFT CODE OF CRIMES AGAINST MANKIND}

Nor has the situation been changed in any way by the International Law Commission's Draft Articles on the Draft Code of Crimes Against the Peace and Security of Mankind. ${ }^{43}$ This does not as such deal with the issue of superior orders. Even though Article 3 states that an individual committing a crime against the peace and security of mankind "is responsible therefore and is liable to punishment," with few exceptions the type of crime listed in the Code aggression, intervention, colonial or alien domination, genocide, apartheid, suppression or mass violation of human rights, recruitment, use, financing and training of mercenaries, wilful and severe damage to the environment are more likely to be committed by governmental authorities than by private individuals, military or civilian. The crimes likely to be committed by individuals are illicit traffic in narcotic drugs, international terrorism ${ }^{4}$ although this has to be committed as 'agent or representative of a State' and exceptionally serious war crimes. The latter are defined ${ }^{45}$ as:

(a) acts of inhumanity. cruelty or barbarity directed against the life. dignity or physical or mental integrity of persons I, in particular wilful killing. torture, mutilation. biological experiments, taking of hostages. compelling a protected person to serve in the forces of a hostile Power, unjustifiable delay in the repatriation of prisoners of war after the cessation of active hostilities, deportation or transfer of the civilian population and collective punishment);

45 Ibid. Art. 22 |brackets in original|. 
(b) establishment of settlers in an occupied territory and changes to the demographic composition of an occupied territory:

(c) use of unlawful weapons;

(d) cmploying methods or means of warfare which are intended or may be expected to cause widespread. long-term and scvere damage to the natural environment;

(c) large-scale destruction of civilian property;

(I) wilful attacks on property of exceptional religious, historical or cultural value.

Many of these crimes reflect the provisions of the Geneva Conventions and Protocols, but for the main part they are not likely to be committed by members of the forces acting on their own initiative, but would rather be committed as a result of orders received from above and would often be a reflection of governmental policy. It is very likely, therefore, that any individual charged with an 'exceptionally serious war crime' would plead superior orders and seek to lay the responsibility for the commission of his act upon some superior.

Article 11 of the Draft is the only one directed at this defence, although the Article must be read in conjunction with Article 14. The former provides: "The fact that an individual charged with a crime against the peace and security of mankind acted pursuant to an order of a Government or a superior does not relieve him of criminal responsibility if, in the circumstances of the time, it was possible for him not to comply with that order." The law of armed conflict recognizes the reality of field situations and that, while superior orders do not constitute a defence, the recipient of an order is unlikely to know the minutiae of the law and may be under a great deal of pressure when the order is given. This is reflected in Article 14 which states that "the competent court shall determine the admissibility of defences under the general principles of law in the light of the character of each crime [and] in passing sentence, the court shall, where appropriate, take into account extenuating circumstances."

The reference to general principles of law, the character of each crime and extenuating circumstances emphasizes the importance of military personnel tried for war crimes appearing before a tribunal made up of military officers aware of war conditions rather than by a municipal criminal court. ${ }^{\text {th }}$

As a counterpart to the provisions on superior orders, the Draft deals with the liability of the superior responsible for issuing an order which would entail the commission of a crime against the peace and security of mankind. Reflecting the position established with regard to the duty of commanders by Articles 86 and 87 of Protocol 1, Articles 12 and 13 of the Draft make it perfectly clear that commission of an offence by a subordinate:

does not relicve his superiors of criminal responsibility, if they knew or had information cnabling them to conclude, in the circumstances at the time, that the subordinate was committing or was going to commit such a crime and if they did not take all feasible measures within thcir power to prevent or 
repress the crime 1 ,while| the official position of an individual who commits a crime against the peace and security of mankind. does not relicve him of criminal responsibility.

It would appear, therefore, that the International Law Commission's draft on crimes against the peace and security of mankind has not made any substantial change to the law with regard to the defence of superior orders. It has merely reiterated the provisions already established in customary law and by the Nuremberg Principles. If the Draft is adopted into treaty, however, it will provide a treaty provision recognizing the limited validity of the defence of superior orders. This will not cover war crimes, but only those described by the International Law Commission as 'exceptionally serious'. They will cover other crimes against peace and security, but not war crimes in the traditional sense nor those acts described in the Geneva Conventions and Protocol I as 'grave breaches'. Insofar as these are concerned, the law as established in customary law and confirmed at Nuremberg and expounded in the Canadian statement at Geneva continues to govern. 